\title{
Effect of Incubation Temperature Climbing Perch (Anabas testudineus Bloch 1792) Eggs on Hatching Rate and Sex Ratio
}

\author{
Muhammad Ali Zulfikar ${ }^{1 *}$, Muhammad², Slamat $^{3}$ \\ ${ }^{1}$ Master Program of Fisheries Science, Lambung Mangkurat University, Indonesia \\ ${ }^{2,3}$ Department of Fisheries Science, Lambung Mangkurat University, Indonesia
}

\author{
DOI: $10.36348 /$ sjet.2020.v05i03.002 $\quad$ | Received: 07.03 .2020 | Accepted: 16.03 .2020 | Published: 18.03 .2020 \\ *Corresponding author: Muhammad Ali Zulfikar
}

\section{Abstract}

The purpose of this study was to analyze the role of the incubation temperature of papuyu fish eggs (Anabas testudinius Bloch 1792) to obtain the ratio of female fish seeds. This research was conducted for 3 months starting from March 2019 until May 2019, at the Wet Laboratory of Lambung Mangkurat University, South Kalimantan Province. Fertilized Climbing Perch eggs are incubated at $20^{\circ} \mathrm{C}, 22^{\circ} \mathrm{C}, 24^{\circ} \mathrm{C}$, and $26^{\circ} \mathrm{C}$ at 12 incubators (small box) with a stocking density of 25 eggs during incubation are observed and calculated the hatchability of eggs after the larvae hatch then cooling down the incubator is stopped. This study uses a completely randomized design (CRD) with 4 treatments and 3 replications, so that it will produce 12 experimental units. The results of analysis of variance (ANOVA) hatchability ranging from 90.67 to $100 \%$ had no significant effect. This study shows that the incubation temperature of papuyu fish eggs gives an effect on the female genital ratio of papuyu with the highest sex ratio in treatment $\mathrm{C}\left(24^{\circ} \mathrm{C}\right)$ of $100 \%$ and the lowest in treatment $\mathrm{D}\left(26^{\circ} \mathrm{C}\right)$ of $65.61 \%$. The DMRT test results show that the sex ratio treatment $\mathrm{C}$ with $\mathrm{D}$ was significantly different also treatment A with $\mathrm{D}$ was different while other treatments were not significantly different.

Keywords: Climbing perch, Incubation, Temperature, Feminization. Copyright @ 2020: This is an open-access article distributed under the terms of the Creative Commons Attribution license which permits unrestricted
use, distribution, and reproduction in any medium for non-commercial use (NonCommercial, or CC-BY-NC) provided the original author and source are credited.

\section{INTRODUCTION}

Papuyu fish (Anabas testudineus Bloch 1792) is a type of fish that has changed its name from Papuyu fish based on Ministerial Decree KP Number 40 / Kepmen.KP / 2014 is an exotic fish typical of peat swamp waters in South Kalimantan with high economic value (Rp. 70,000 - 120,000/ kg), the taste of the meat is tasty and can be processed into a variety of dishes such as grilled, fried, pepes, old, wadi [1]. The needs of papuyu fish in South Kalimantan in meeting the demands of their fans reach> $900 \mathrm{~kg} /$ day, where only $40 \%$ are met, and $80 \%$ of the sources come from catches in the wild and only $20 \%$ of aquaculture [2].

Cultivation of single sex (monosex) female papuyu fish has the potential to shorten the maintenance period, and increase production [3]. The sex of an individual is determined together by genetic and environmental factors. Genetically the sex is determined by the pair of chromosomes which are inherited by the parent. Functionally the sex of the fish is determined by the environment during fish gonad development. Environmental factors that affect gonad development include temperature, $\mathrm{pH}$ and exogenous steroids [4].

Enlargement of female papuyu is faster than male in general, the ratio of growth of female and male is $270 \%$ [2]. According to Nur'ain [5] papuyu fish maintenance by female monosex can increase fish growth by $134.92 \%$ from male monosex maintenance and $29.94 \%$ from mixed maintenance. Papuyu fish culture with a system of "monosex culture" will certainly be able to increase production efficiency both in terms of time and cost because female body size is greater than males. From the field identification in general, the technical problem of papuyu fish farmers is the percentage of males born more than females [1].

Yamamoto [6] states that the success of changing sex is influenced by several factors, namely the type and dose of the hormone used, the length of treatment, fish species, the age of the fish during the treatment and the water temperature at the time of the treatment. The process of directing sex can be done by manipulating the ambient temperature. Temperature is a factor that can influence the speed of chemical reactions 
in the body such as the metabolic rate [7]. Added by Baroller et al. [8], sexual differences in fish (sex ratio) can be influenced by environmental variables such as temperature. Factors that play a key role in determining the sex of several fish species are temperature, irradiation, rainfall, and salinity in many fish species [9].

Egg hatchability or hatching rate is the percentage of eggs that hatch after a certain time hatch is the last incubation period as a result of several processes so that the embryo comes out of the shell. The hatching of eggs occurs because of mechanical and enzymatic work because mechanical embryos often change their position due to lack of space in their shells or because the embryos are longer than their environment in the shell [10]. In general the incubation temperature of papuyu fish eggs from $28-34^{\circ} \mathrm{C}$. Putri [11] reported that the optimal incubation temperature for papuyu fish eggs was $34 \mathrm{oC}$ with hatchability of $98.66 \%$ while Imaryanti [12] that the temperature of $28^{\circ} \mathrm{C}$ was better than $32^{\circ} \mathrm{C}$ but this study does not explain the results of the sex ratio according to the author's purpose. Other results with an incubation temperature of $16-20^{\circ} \mathrm{C}$ get a percentage of $93.33 \%$ where the best temperature is $16^{\circ} \mathrm{C}$ [13].

\section{RESEARCH METHODS}

This research will be carried out for 3 months starting from March 2019 until May 2019, at the Wet Laboratory of Lambung Mangkurat University, South Kalimantan Province. In the management of this experiment, the first step that must be taken is to prepare the mature papuyu broodstock gonads originating from the UPR (People's Hatchery Unit) with a ratio of 3: 1 male and female before spawning, styrofoam containers with a size of $70 \times 40 \times 30 \mathrm{~cm}$, first clean first. This study requires a stable and homogeneous temperature in each repetition to incubate eggs at the appropriate temperature treatment so that an incubator with good cooling is needed. The incubator used in this study was made of styrofom with 70r each cooled on styrofoam using ice water.

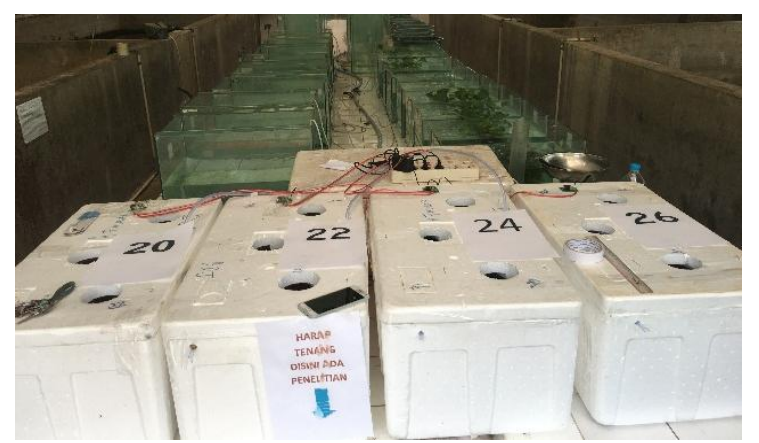

Fig-1: Styrofoam with a size of $70 \times 40 \times 30 \mathrm{~cm}$

The temperature of the cooler is regulated and maintained automatically using a digital thermostat that will detect the temperature of the cooler, if the temperature of the cooler rises $0.5^{\circ} \mathrm{C}$ from the setting temperature then the thermostat will turn on the pump that will flow ice water to the cooler so that the temperature will go down as desired. This happens repeatedly with a refresh rate of 0.5 seconds and will start the pump at a rise of $0.5^{\circ} \mathrm{C}$ from the desired temperature of $20^{\circ} \mathrm{C}, 22^{\circ} \mathrm{C}, 24^{\circ} \mathrm{C}$ and $26^{\circ} \mathrm{C}$. The incubator design can be seen can be seen in Figure 2 below.

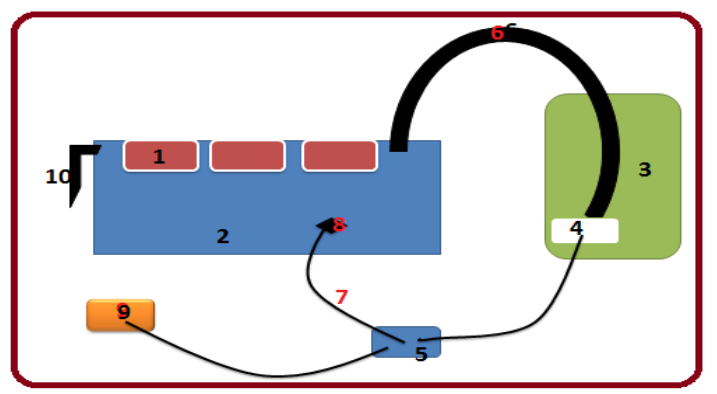

Fig-2: Cooling Incubator Design

Information
\begin{tabular}{|c|l|l|l|}
\hline 1. & Incubator & $\mathbf{6 .}$ & Water hose \\
\hline 2. & Cooling water & 7. & Wires \\
\hline 3. & $\begin{array}{l}\text { Ice } \\
\text { container }\end{array}$ & $\begin{array}{l}\text { Water } \\
\text { sensor }\end{array}$ \\
\hline 4. & Mini water pump & 9. & Power source \\
\hline 5. & Digital thermostat & 10. & Duct drain \\
\hline
\end{tabular}

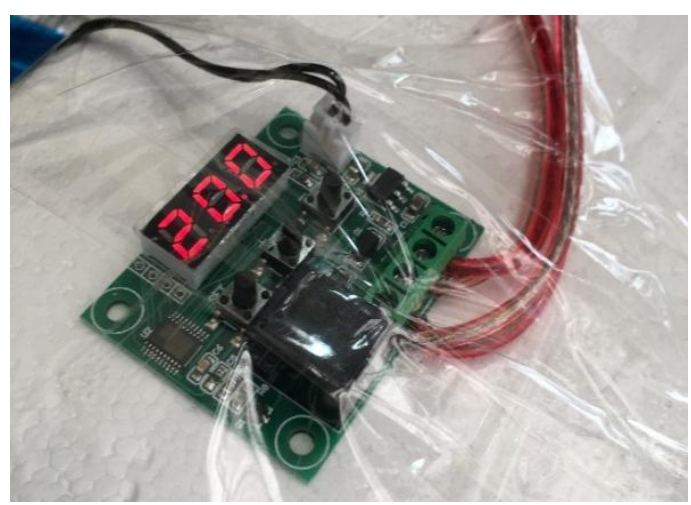

Fig-3: Digital Thermostat

After the container is available the female parent is injected with ovaprim at a dose of $0.5 \mathrm{cc} / \mathrm{kg}$ intramuscular injection of the parent in the back muscles of the female parent 2 times of injection and the male parent of 1 injection. This dose is in accordance with research [14] which states a dose of 0.5 is sufficient because papuyu fish are in a normal state. spawned fish eggs that have been fertilized are incubated in 12 incubators (small basins) with a stocking density of 25 eggs during incubation are observed and egg hatchability is calculated after hatching larvae then cooling in the incubator is stopped, newly hatched larvae will be kept in the incubation place until incubation incubator temperature in each treatment is the same, it is intended that the larvae are not surprised by the temperature change drastically for 15 days. After the incubator temperature is the same, 
continued maintenance of larvae in the larvae will be maintained in the basin for 15 days with natural food Daphnia sp taken from the feeding pond carried out twice a day in the morning and evening after the yolk is gone and interspersed with pellet feed feng li 0 on the 10th day.

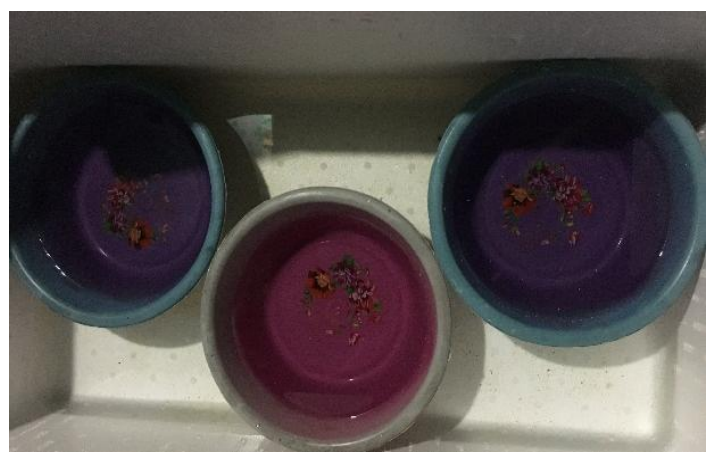

Fig-4: Maintenance of Papuyu Fish Larvae

Morphological observations of males and females were carried out when larvae were $30 \mathrm{hpt}$.
Observations are made by looking at morphology. If a small body, a narrow body and put in water at the level of his back always wants to stand up, it can be ascertained male, but if a large body, large body and put in water at the level of his back always wants to move to and fro a female can be ascertained. This study uses a completely randomized design (CRD) with 4 treatments and 3 replications, so that it will produce 12 experimental units.

The parameters observed in this study are hatchability, genital nibah, and water quality. The hypothesis used in this study is as follows: The lower the temperature, the more females are than males.

\section{RESULTS AND DISCUSSION Hatching Rate}

The results of the calculation of hatching rate of papuyu fish eggs are presented in Table 1 and the average is presented in Figure 5.

Table-1: Average value of papuyu fish egg hatcing rate (\%)

\begin{tabular}{|c|r|r|r|r|r|}
\hline Treatments & \multicolumn{1}{|c|}{$\mathbf{1}$} & \multicolumn{1}{c|}{$\mathbf{1}$} & \multicolumn{1}{c|}{$\mathbf{3}$} & Total & Means \\
\hline $\mathrm{A}$ & 100 & 100 & 100 & 300 & 100.00 \\
\hline $\mathrm{B}$ & 92 & 96 & 100 & 288 & 96.00 \\
\hline $\mathrm{C}$ & 88 & 96 & 96 & 280 & 93.33 \\
\hline $\mathrm{D}$ & 84 & 88 & 100 & 272 & 90.67 \\
\hline \multicolumn{5}{|c}{ Note: $\mathrm{A}=\left(20^{\circ} \mathrm{C}\right), \mathrm{B}=\left(22^{\circ} \mathrm{C}\right), \mathrm{C}=\left(24^{\circ} \mathrm{C}\right), \mathrm{D}=\left(26^{\circ} \mathrm{C}\right)$}
\end{tabular}

Table 1 shows the average percentage of papuyu fish egg hatching rate in each treatment that ranged from $90.67 \%$ to $100 \%$, where the average in treatment A was $100 \%$, the average treatment B was $96 \%$, the average treatment $\mathrm{C}$ was $93.33 \%$, and the average treatment D was $90.67 \%$.

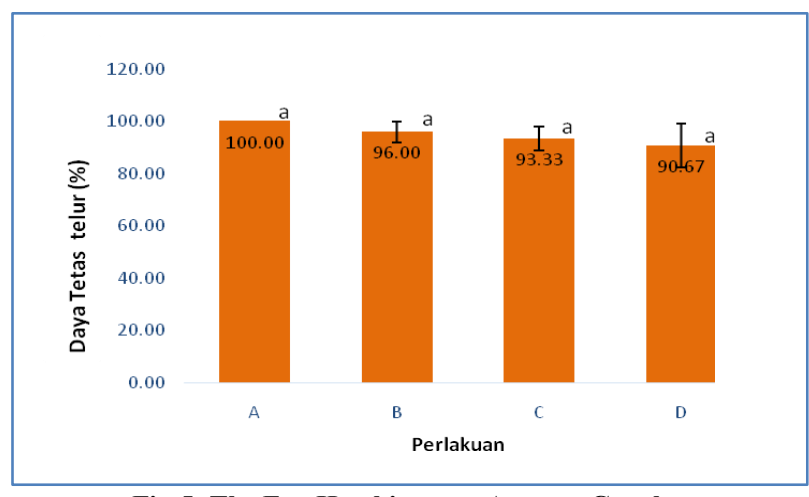

Fig-5: The Egg Hatching rate Average Graph

Note: $\mathrm{A}=\left(20^{\circ} \mathrm{C}\right), \mathrm{B}=\left(22^{\circ} \mathrm{C}\right), \mathrm{C}=\left(24^{\circ} \mathrm{C}\right), \mathrm{D}=\left(26^{\circ} \mathrm{C}\right)$

Figure 5 shows that the average percentage of hatchability of papuyu fish eggs in each treatment varies. The highest percentage of hatchability was at treatment $\mathrm{A}$ (temperature $20^{\circ} \mathrm{C}$ ) at $100 \%$, followed by treatment $\mathrm{B}$ (temperature $22^{\circ} \mathrm{C}$ ) at $96 \%$, then treatment $\mathrm{C}$ (temperature $24^{\circ} \mathrm{C}$ ) at $93.33 \%$ and the lowest at treatment $\mathrm{D}$ (temperature $26^{\circ} \mathrm{C}$ ) of $90.67 \%$. The results of the Liliefors normality test and Bartlett's homogeneity of the percentage of hatchability of papuyu fish eggs showed that the data spread was normal, $\mathrm{Li}_{\max }(0.189)<\mathrm{Li}_{\text {table }} 5 \%(0.242)$ and $1 \%$ $(0.275)$ and homogeneous variant data $X^{2}$ count $(8.33438)$ $<\mathrm{X}_{\text {table }}^{2} 5 \%(5,991)$ and $1 \%(9,21)$. Analysis of variance analysis (ANOVA) showed that the treatment did not significantly affect the hatchability of papuyu fish eggs as evidenced by the value of $F_{\text {count }}(1.7833)>$ $\mathrm{F}_{\text {table }}$ 5\% (4,076).

Egg hatchability is the percentage of eggs that hatch after a certain time. Hatching is the last moment of incubation as a result of several processes so that the embryo comes out of the shell, this temperature hatching process plays a very important role [10]. The process of hatching eggs will be disrupted at high temperatures so that it can cause damage to the egg cell tissue. Very high temperatures will accelerate the rate of hatching of eggs so that eggs cannot go through the phases of hatching eggs perfectly [15]. The observations showed that the highest egg hatchability was in treatment A by $100 \%$ compared to other treatments. The higher the incubation temperature shows the lower hatchability. According to Halimi [13] the temperature range of papuyu hatching eggs at low temperatures ranging from $20^{\circ} \mathrm{C}$ to $16^{\circ} \mathrm{C}$ has increased hatchability. 
Sex Ratio

The results of the calculation of the percentage of female sex ratio of papuyu fish are presented in table 2 and the mean percentage of sex ratio.

Table-2: Percentage of Female Sex Ratio of Papuyu Fish (\%)

\begin{tabular}{|c|c|c|c|c|c|}
\hline Treatments & 1 & 2 & 3 & Total & Means \\
\hline A & 100.00 & 92.31 & 100.00 & 292.31 & 97.44 \\
\hline B & 63.64 & 80 & 100.00 & 243.64 & 81.21 \\
\hline C & 100.00 & 100.00 & 100.00 & 300.00 & 100.00 \\
\hline D & 66.67 & 85.71 & 44.44 & 196.82 & 65.61 \\
\hline
\end{tabular}

Table 2 shows the average percentage of female genital ratio of papuyu fish in each treatment which ranged from $59.09 \%$ to $100 \%$, where the mean in treatment A was $97.44 \%$, the average treatment B was $59.09 \%$, the average treatment $\mathrm{C}$ was $100 \%$, and the mean treatment D was $84.13 \%$.

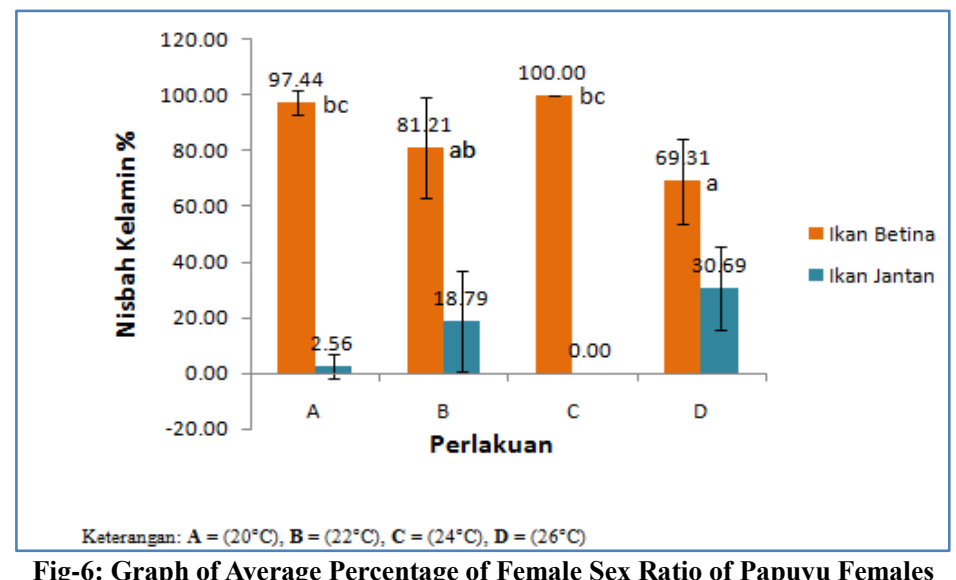

Figure 6 shows that the average percentage of female genital ratio of papuyu in each treatment varies. The highest percentage of hatching power was at treatment $\mathrm{C}$ (temperature $26^{\circ} \mathrm{C}$ ) at $100 \%$, followed by treatment $\mathrm{A}$ (temperature $20^{\circ} \mathrm{C}$ ) at $97.44 \%$, then treatment $\mathrm{B}$ (temperature $24^{\circ} \mathrm{C}$ ) at $81.21 \%$ and the lowest at treatment $\mathrm{D}$ (temperature $22^{\circ} \mathrm{C}$ ) at $65.61 \%$.

The results of Liliefors normality test and Bartlett homogeneity variability on the percentage of papuyu fish hatchability showed that the data spread was normal, $\mathrm{Li}_{\max }(0.271)<1 \% \quad(0.275)$ and homogeneous variant data $X^{2}$ count $(11.39)<X_{\text {table }}^{2} 5 \%$ (5.99) and $1 \%$ (9.21). Analyst results (ANOVA) showed that the treatment significantly affected the genital ratio of papuyu fish as evidenced by the value of $\mathrm{F}_{\text {count }}(4.27)>\mathrm{F}_{\text {table }} 5 \%$ (4.06). DMRT test results showed that treatment $\mathrm{C}$ with $\mathrm{D}$ were significantly different also treatment A with D differed while other treatments were not significantly different.

The results showed that the female sex ratio in all treatments was more than $50 \%$ so that the water temperature was very influential in the formation of male or female genital papuyu fish as evidenced by the DMRT test that between different treatments, higher temperature treatments $\left(26^{\circ} \mathrm{C}\right)$ produced a female sex ratio lower than male sex. According to the findings of Yamamoto [6]; Webb [7]; and Baroler et al. [8] that one of the successes in changing the sex ratio of fish is water temperature. Furthermore [16] temperature also influences the sex of fish. Poeilipsis lucida rearing at low temperatures will produce a percentage of females between $80-100 \%$. Whereas at normal temperatures (25-27 C) male sex will be produced higher, ranging from $60-70 \%$ [17]. An increase in temperature can accelerate the action of the hormones testosterone and ketotosteron thus increasing the percentage of males compared to females [18].

This research can be known that the use of $24^{\circ} \mathrm{C}$ temperature is better in producing female genital ratio which is $100 \%$ compared to soaking of larvae using avocado and milk, also decreasing the temperature with canopy and using ice cubes. All of the above treatments are not known for the long-term effects that will be received by fish and consumers. It would be nice to study the sex ratio using natural ingredients to further research.

\section{Water Quality}

Hatchability and survival in papuyu fish larvae are influenced not only by the availability of natural food, but also by water quality. The results of water quality measurements in this study can be seen in table 3. 
Muhammad Ali Zulfikar et al., Saudi J Eng Technol, March. 2020; 5(3): 101-105

Table-3: Results of water quality measurements at the beginning and end of the study

\begin{tabular}{|c|l|l|}
\hline Parameter & Initial & Final \\
\hline $\mathrm{pH}$ & 6,7 & 7 \\
\hline $\mathrm{DO}$ & $6,2 \mathrm{ppm}$ & $5,3 \mathrm{ppm}$ \\
\hline Temperature & $26^{\circ} \mathrm{C}$ & $27^{\circ} \mathrm{C}$ \\
\hline
\end{tabular}

From the results of measurements during the study the water temperature ranged between $26-27^{\circ} \mathrm{C}$. Papuyu fish generally like the temperature range of 25$33^{\circ} \mathrm{C}[19]$ this shows that the water temperature in this study is still in a fairly normal state and good for the survival of the female larvae. Dissolved oxygen content (DO) obtained during the study ranged from 5.3 to 6.2 ppm, Helmizuryani [3] oxygen levels suitable for the survival of papuyu fish are $<3-4 \mathrm{ppm}$, this means that oxygen measurements during the study are still supportive for the survival of papuyu fish. A good $\mathrm{pH}$ range for growth and survival of the male fish between 6-8. During the study ranged from 6.7 to 7 so the $\mathrm{pH}$ range during the study was quite good for the life and growth of papuyu fish. According to Rahmi [20], that $\mathrm{pH}$ tolerance in water is influenced by many factors including, temperature, dissolved oxygen and the adjustment of fish to the environment.

\section{CONCLUSION}

Based on the results of research that has been done, it can be concluded that: temperatures $20^{\circ} \mathrm{C}$, $22^{\circ} \mathrm{C}, 24^{\circ} \mathrm{C}, 26^{\circ} \mathrm{C}$ can effectively direct the female genital ratio of papuyu fish [2]. The highest female sex at $24^{\circ} \mathrm{C}(100 \%)$, followed by $20^{\circ} \mathrm{C}(97.44 \%), 22^{\circ} \mathrm{C}$ $(81.21 \%)$ and $26^{\circ} \mathrm{C}(65.61 \%)$.

\section{REFERENCES}

1. Slamat dan Pahmi. A. (2013). Fekunditas Ikan Betok di perairan rawa monoton Kalimantan Selatan. Jurnal Pendidikan Lingkungan, 1(2).

2. Slamat, Ansyari, P., \& Fatmawati. (2017). Optimalisasi Penetasan Sel Telur F2 Ikan Papuyu (Anabas testudineus Bloch 1972) dengan Sistem Kanopi dalam Upaya Meningkatkan Nisbah kelamin Ikan. Seminar Nasional Kelautan XII, 2531.

3. Helmizuryani, Muslimin, B., \& Khotimah, K. (2017). Pembetinaan ikan betok, Anabas testudineus (Bloch, 1792) menggunakan larutan susu dan kedelai melalui perendaman larva. Jurnal Iktiologi Indonesia, 17(2), 123-132.

4. Irwansyah, B. (2015). Perubahan Kelamin Jantan Benih Ikan Lele Sangkuriang (Clarias sp) Pada Umur Berbeda Dengan Perendaman Hormon 17 $\alpha$ Metiltestosteron., Meulaboh: Universitas Teuku Umar.

5. Nur'ain, S. (2017). Variasi Penggunaan Kanopi Wadah Penetasan Telur Papuyu (Anabas testudineus Bloch 1792) untuk Meningkatkan Jumlah Betina.

6. Yamamato, TO. (1969). Sex Differentiation: In WS Hoar, DJ Randall, eds. Fish Physiology, Volume
III. Academic Press, New York, NY, USA, 117177.

7. Webb, P. W. (1978). Partitioning of Energy into Metabolism and Growth, 184-214. In: S. D. Gerking (Ed.). Ecology of Freshwater Fish Production. Blackwell Scientific Publications, Oxford.

8. Baroiller, J.F., Chourrout, D., Fostier, A., Jalabert, B. (1995). Temperature and sex chromosomes govern sex ratios of the mouthbrooding Cichlid fish Oreochromis niloticus. J Exp Zool, 273: 216-223.

9. Jobling, M. (1995). Environmental biology of fishes. London: Chapman \& Hall.

10. Farida, R., \& Adrianus. (2016). Pengaruh Suhu yang Berbeda terhadap Waktu Penetasan dan Kelangsungan Hidup Larva Ikan Biawan (Helostoma temmincki). Jurnal Ruaya, 4(2), 63-69.

11. Putri, D.A., Fitrani, M. (2013). Persentase penetasan telur ikan betok. Jurnal Akuakultur Rawa Indonesia, 1(2): 184-191.

12. Imaryanti. (2014). Pengaruh Perbedaan Suhu Terhadap Daya Tetas Telur dan Persentase Abnormalitas Larva Ikan Betok (Anabas testudineus)., Banda Aceh: Universitas Syiah Kuala

13. Halimi. (2019). variasi suhu rendah pada penetasan telur ikan papuyu (Anabas testudineus Bloch 1792) untuk meningkatkan kelahiran betina. kementrian riset teknologi dan pendidikan tinggi universitas lambung mangkurat. Banjarbaru kalimantan selatan.

14. Suriansyah, A. (2011). Landasan pendidikan. Banjarmasin: Comdes.

15. Amri, K. Dan Khairuman. 2003. Budidaya Ikan Nila Secara Intensif. Jakarta: Penerbit Agromedia Pustaka.

16. Devlin, R. H., \& Nagahama, Y. (2002). Sex determination and sex differentiation in fish: an overview of genetic, physiological, and environmental influences. Aquaculture, 208(3-4), 191-364.

17. Oshiro, N., Fukata, Y., \& Kaibuchi, K. (1998). Phosphorylation of moesin by rho-associated kinase (Rho-kinase) plays a crucial role in the formation of microvilli-like structures. Journal of Biological Chemistry, 273(52), 34663-34666.

18. Arfah, H., \& Mariam, S. Alimuddin. (2005). Pengaruh suhu terhadap reproduksi dan nisbah kelamin ikan gapi Poecilia reticulate Peters. Jurnal Akuakultur Indonesia, 4(1), 1-4.

19. Noorani, S., Seyyed Alavi, G., \& Kordi, M. (2000). Efficacy of acupressure on reduse nasea and vomiting in the first trimester of pregnancy. Med $J$ Mashhad Univ Med Sci, 24(66), 89-95.

20. Samaha, E., Rahmi, G., Landi, B., LorenceauSavale, C., Malamut, G., Canard, J. M., \& Cellier, C. (2012). Long-term outcome of patients treated with double balloon enteroscopy for small bowel vascular lesions. American Journal of Gastroenterology, 107(2), 240-246. 